\title{
ARCHITECTURE IN CRISIS
}

EXCEPTION AS A FORM OF DECAY

\author{
Although Agamben defines the camp (concentration \\ or refugees camp) as the paradigm of the state of \\ exception, this statement overlooks not only the \\ physical and spatial conditions of the camp, but also \\ everyday practices that take place inside. Analyzing \\ the spatial practices in current refugee camps in \\ Turkey, the text shows that its design often forgets \\ the very humanity of the refugee.
}

KEYWORDS - camps, refugees, biopolitics, commoning, Turkey

\section{EXCEPTION}

A camp is often described as a spatialization of exception. Space of exception refers to judicial condition of where normal law is suspended by structures of hegemony. The main argument - provided by Carl Schmitt in his Political Theologyis that "state of exception" is decided by sovereignty and that this argument is based on political and judicial power (Schmitt, 2005). For Agamben -who expands on Schmitt's conceptualization- "The state of exception is not a special kind of law (like the law of war); rather, insofar as it is a suspension of the juridical order itself, it defines law's threshold or limit concept" (Agamben, 2005:4). Moreover, by analyzing Carl Schmitt's theory of the state of exception Agamben claims that "being-outside" and "belonging" is the "topological structure of the state of exception, and only because the sovereign, who decides on the exception, is, in truth, logically defined in his being by the exception, can he too be defined by the oxymoron ecstasy-belonging" (Agamben, 2005:35). So, in relation to space or topos, 'exception' is basically a practice of hegemony of de-territorialization exercised precisely by territorialization; a form of practice of exclusion by exercising inclusion. As Agmben argues, "since 'there is no rule that is applicable to chaos,' chaos must first be included in the juridical order through the creation of a zone of indistinction between outside and inside, chaos and the normal situationthe state of exception" (Agamben, 1998:19). Therefore, if we look at it from the perspective of spatial practice, it is a formation based on the demarcation of space. In the last ten 


\section{Pelin Tan}

Profesora, Facultad de Arquitectura, Artuklu University, Mardin, Turquía

years, the discussion and interpretations of 'exception' in terms of topography and urbanism are extended with examples of extra-territorialities of civil war (Franke, 2003), occupied territories, liquid borderlines, islands, buffer zones, curfew cities, state-led urban transformations, evictions and others (Franke; Weizman, 2003). Thus, the contemporary experience of 'exception' as a form is a multiple constellation that exists in tension between territorial facts, objects, and subjectivities.

In this article, the refugee camp is discussed as one of the main practices of exception. Since Agamben claimed that the camp is a biopolitical paradigm (Agamben, 1998), they are often described as spaces of a state of exception. However, as his claim is based on a Western paradigm, we could argue that the 'camp' -both as a reality of today as it is hosting refugees and also as a metaphorical entity-could leads us to focus on the layers and practices of the subjectivity and its territory.

Ontologically, the refugees are often described as the ones that are excluded by being included in a camp, as victims of the state of exception. How can we analyze this differently, looking at the potentials and the emancipative role of refugees in the camp? How can we claim an emancipative practice and role in a camp or a space of resistance against structures of hegemony? Agamben's approach, which is often referred to, says:

...if the essence of the camp consists in the materialization of the state of exception and in the subsequent creation of a space in which bare life and the juridical rule enter into a threshold of indistinction, then we must admit that we find ourselves virtually in the presence of a camp every time such a structure is created, independent of the kinds of crime that are committed there and whatever its denomination and specific topography (Agamben, 1998:19).

Camps are seen as biopolitical spaces in which subjectivity and otherness are ontologically justified; however, this approach clearly leaves out the potentialities of subjectivity as well as the territorial conditions. Therefore, the becoming of the subjectivity of a refugee is trapped in such a 'victimhood' discourse, in the camp and also as the subject of the sovereignty.

Although Critchley interprets Levinas's primary ethical ontology as "active nihilism" for the emancipation and the ethic of the subjectivity through the otherness (Critchley, 2007), he might see Agamben's camp as space of exception and as a prevention of the potentials of emancipation by default (Critchley, 2012). In Petti \& Hilal's practice in DAAR and Campus in Camps, the refugee -as a subjectivity-is a potential citizen beyond nation-state construction. We may also 


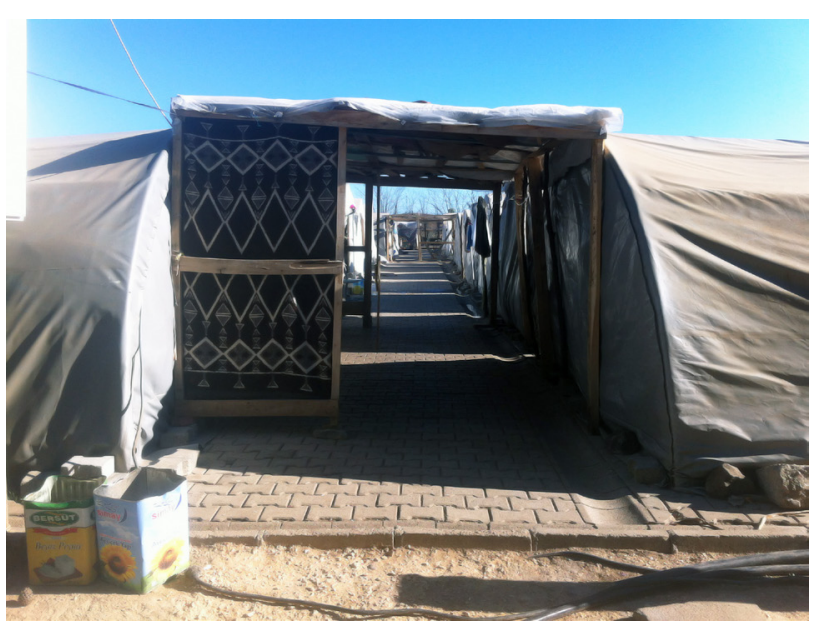

FIG 1 Çınar Yezidi Camp, Diyarbakır, 2015 (C) Pelin Tan remember the approach of New York based artist and designer Krzysztof Wodiczko with his The Homeless Vehicle Project (that he designed together with New York homeless community) or the City of Refugee in our current urban life: they present the refugee as the archetype of the subjectivity that claims for his right to the city and his role in urban participation (Wodiczko, 1990). Homeless, gypsy, refugee, nomad... such biopolitical subjectivities are the artifacts of the survival strategies in urban life, and are at the border between exclusion and inclusion. From the perspective of Levinas philosophy, a refugee experiences the otherness by being the otherness. According to poet Etel Adnan, we are all refugees. A refugee is the subjectivity of an unconditional hospitality. Being a refugee -or the experience of a refugee space- is about facing the experience of radical space. In Levinas, the ethical a priori condition is based on understanding subjectivity through the other. To draw from the theoretical constellation of Schmitt/ Levinas/Agamben, subjectivity is defined in the condition of exception. ${ }^{1}$ Defining the refugeehood in this theoretical framework brings the criticism of constraining the refugee's emancipation as a subjectivity. It diminishes the potentials of the transversal subjectivity as a refugee. Being a victim, an aggrieved, the otherness, among other things, reduces the emancipatory role in an ethical ontology of the subjectivity.

\section{CAMP}

The everyday life practice of a refugee community in a camp is often applied by a normative design approach. Its public space is understood as a tabula rasa, an empty bowl. If we look into refugee camp literature in architecture, the basic arguments are about its urbanization process, spatial practices and understanding the space of camp as a state of exception. "Camps-villes," as defined by anthropologist Michel Agier: "...the camps gradually become the sites of an enduring organization of space, social life and system of power that exist nowhere else. These are paradoxical devices, hybrids that, for lack of an appropriate term, I shall call city-camps (camps-villes)" (Agier, 2002). Agier defines the refugee camp as a socio-spatial entity. Even though the link between the concepts of camp and city paradoxically signifies the problems of normative design, Agier is conceptualizing it in the context of urbanization; as the space of a camp has a heterogeneous everyday life, as a biopolitical space has networks of practices of the actors and agencies. Architects such as Manuel Herz, Alessandro Petti and Sandi Hilal provide basic theoretical argumentation, empirical data and experiences on refugee camps (Hilal, 2008; Petti, 2013). According to his research on refugee camps in Africa, Herz claims that refugee camps are not 'non-places' as they have often been described in social sciences. In contrast,

1 This discussion is beyond the scope of my article; hence I cannot mention it more rightfully. However, I strongly recommend a book in Turkish by Duygu Türk. She makes detailed analyses and argumentation in her book about the comparison between Ethics and Politics according to Levinas, Schmitt, and Badiou. See: Türk, 2013 


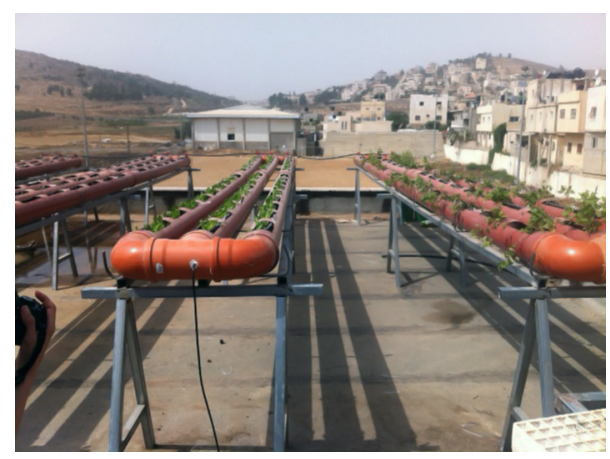

FIG 2 AlFawar Palestinian Refugee Camp, Roof of Women Center, 2015 (C) Pelin Tan

the space of a camp is a settlement; a territory containing political, economic, and judicial relationships, which also transforms the relationships of outside world (outside the camp). Thus, for Herz, the whole relationship is the spatialization of the camp (Herz, 2008). Furthermore, Herz also claims that refugee camps are the direct materialization of the dynamic political act against urban forms, which are idealized by the West. In this context, as a biopolitical space of an anti-colonization city and settlement, it is a potential spatial practice against Western oriented modernism and global colonial dwelling forms. Petti and Hilal, established a practice, a methodology and a theory as DAAR, decolonizing practices in a camp in the West Bank. They are concerned with the question of public space and the ways of interacting in refugee camps (which are almost urbanized). Hence, Petti asks a counter-question:

If a citizen's political identity is played out in the public space of the city, what is found in the camp is its inverse: here, a citizen is stripped of his or her political rights. In this sense, the camp represents a sort of anti-city, a constitutive void of a political order. But what effect does this anti-city produce on the public and political space of the city? (Petti, 2015).

Through the problematization of public space he claims that the camp has potential as an "anti-city". As a biopolitical space, camps cannot be conceptualized through a dichotomy of inside-outside, or segregation between outside world. A camp is beyond such a dualistic structure (Petti, 2015). Beyond Western oriented public space discussion and nation-state citizenship participation, both Petti and Hilal are focusing on a new term/practice called Al-Masha (Tan, 2015). The meaning of the word is equivalent to 'common' and the practice has an Ottoman legacy where production and cultivation of land is done in community. Referring to this concept they introduce similar meaning and practice of the 'commons'. Camps offer the practice of commoning for life and solidarity forms (Petti, Hilal, Weizman, 2014). Architectural and critical spatial practice in occupied lands in the West Bank are based on the question of Al-Masha, testing the potentiality of a new formation of citizen, a space beyond public/private dualism and decolonizing practice of re-using functions of settlement. 


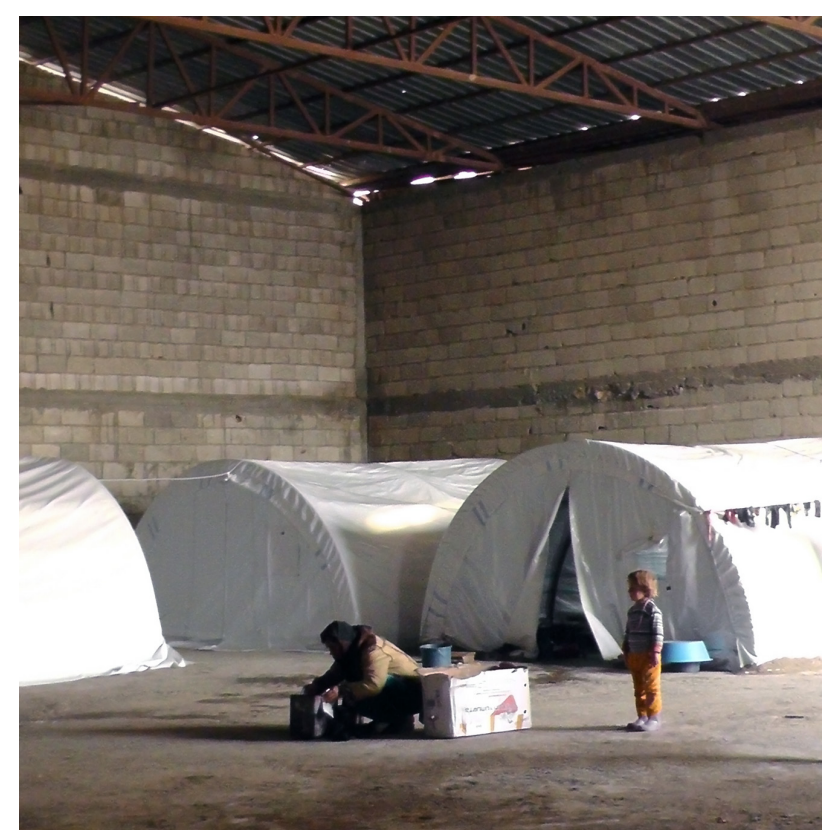

FIG 3 Suphi Nejat Ağırnaslı Tent Camp (in a factory), Suruç, 2014 (C) Pelin Tan

As an outcome of the Syrian civil war and conflict in southern Kurdish zones, another case of camp settlement has been recently expanding in the Southeast region of Turkey where the Architecture Faculty of Mardin Artuklu University is based. We have conducted spatial research on camps, which consist of several types of formations and embody the political and social negotiations. ${ }^{2}$ The research focuses on the factors we think are basic in the decision of producing space and in the design of camps:

I) A biopolitical analysis of camps that are constructed, controlled and run by Turkish Government and the UN.

II) The shifting uses in the everyday life practices of refugees of the public space and facilities that are defined in the design program.

III) Gestures of design without architects in the camps.

IV) Infrastructure in temporary camps both officially run by the State and camps that were created by individual initiatives in already existing buildings such as bus stations, art galleries, sport halls, unfinished constructions and empty factories.

As an example of a biopolitical and multiple actors' space, Midyat Refugee Camp which is in the north of Mardin, near the Syrian border, was designed in March, 2013 to host 10,000 people (that year hosted 6,500 Syrians) and by 2015 hosted 3,037 Syrians and 1,721 Iraqi migrants. According to the report of one of our graduate students who was leading the design team on the

2 Midyat Refugee Camp research studio, March 2014, Studio leaders: Pelin Tan \& Markus Miessen, M AU Architecture Faculty, Mardin. Forensik Mimarlık - Socio Spatial Research of Refugee Camps in Southeast Turkey, Principal Researcher: Assoc. Prof. Dr. Pelin Tan, Researcher: Architect Ömer Faruk Günenç, funded by Mardin University Scientific Research Project Department (B AP), 2015-16. 


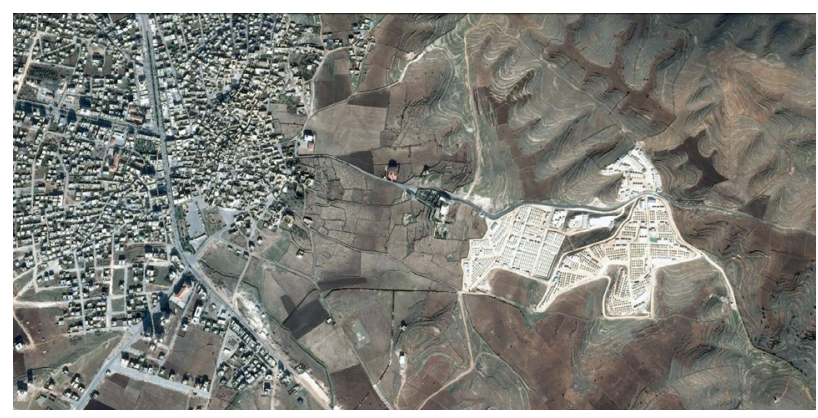

FIG 4 Midyat Camp, Turkey

Fuente / Source: Google Earth ${ }^{\mathrm{TM}}$

camp, three determinants played a role in the designing of the camp: topography, demand by the Assyrian community, and surveillance. ${ }^{3}$ In terms of topography, the terrain was rugged and had differences in elevation: the land had to be flattened by an external intervention. Therefore, the site was transformed into a flat land ready for water and electricity installations, and dwellings. Another important element that influenced the design decision was the Assyrian request of being separated from Muslim Syrians. So, two main dwellings (neighborhoods) were designed; one for Muslims and another for Christian Syrian refugees. The north section of the camp was designed for administration (AFAD: State Department for Natural Disaster Aid Team, Police, Soldiers), the middle section was for Muslims and south part for Christians. Separating the two communities as two islands according to the will of Assyrians led to expanded forms of security. The administration tents were placed in the north of camp, in order to easily control the rest from above. The security and surveillance of the camp was designed in multiple levels in order to control any threat, which is basically an unknown threat. The two communities are separated by a buffer zone known as the security road. The other roads that are used for the transportation of people and life stock are enclosed by a fenced wall. The surveillance huts are similar to open-air prisons. Common facilities like TV rooms, recreation grounds and other public spaces are designed for the common use of two strictly spatially separated communities. As there isn't any serious threat from neither the inside nor the outside of the camp, the surveillance and security determinants play the role of empty signifiers and the design is justified through the control of biopolitics. ${ }^{4}$ According to Yıldırım, the most difficult part in the designing of the camp was designing two separate settlements in the camp but common facilities such as health

3 Interview held between March 3 to March 5, 2014 with Habat Mehmet Yıldırım, architect/designer of Midyat Refugee Camp, Urban Planning Department of Turkish Government, Mardin. (Master Student of MAU Architecture Faculty, Mardin). Further reference: "Midyat Çadırkent (Mülteci Kampı) Planlama Süreci, Sonrası ve Alternatif Kamp Önerisi" (The Process of Midyat Tent Camp and Alternative Camp Design Proposal), Term paper of seminar by Habat Mehmet Yıldırım, in "Things, Animizm, Territory" postgraduate course by Assoc. Prof. Dr. Pelin Tan, MAu Mardin.

4 This is an analysis by Mark Wigley presented during the discussion at the conference "2000+: The Urgencies of Architectural Theory," held at Columbia GSAPP Wood Auditorium on April 18, 2014. The comment helps to clarify the zoning plan, the design of the camp, the unknown embedded knowledge in and around the camp. 
care, food, sport, management, social space and other public spaces. With a large budget for creating an infrastructure design and a surveillance system, such camps remain as biopolitical spaces of negotiation and action of several actors.

The recent temporary tent camps for Ezidi communities who escaped from Shengal and Kobéne to Turkey are mostly placed in existing buildings or in self-initiated tent camps around the towns of Mardin and Suruç in 2014. The actors are the recent Kurdish municipalities, solidarity groups and several international NGOs who intervene such dwellings through politics of humanitarian aid and solidarity discourses. However, refugees continue to be self-organized around their tribes and families, and create ad-hoc design solutions according to commoning practices. For example, the newly designed local bus station of Mardin hosted around 600 refugees from Shengal and was was managed by the Kurdish party and the municipality. A young member of the leading family of the community managed the kitchen of the camp. Local voluntary teachers ran a school made of a large tent from Mardin. Creating a life form through everyday dwelling opens up several self-organized modalities in which design continues to be an ad-hoc solution instead of a control of biopolitics.

\section{DECAY}

I see urbanized and temporary refugee camps as forms of 'decay,' a subtractive building process that is both about anachronism and a decay of architecture itself. I see that the experience of such ad-hoc infrastructure as camps or tents cannot be placed entirely within the context of a state of emergency or a limited spatial form of exception (Tan \& Hüner, 2015). The decay of forms compels us to deal with anachronisms that do not withhold the 'humanity' rooted in human history. Reza Negarestani has asked: "Is decay a positive or negative building process?" and he adds, "the building process of decay is subtractive, which is to say, it is concurrently intensively negative and extensively positive" (Negarestani, 2010). The contraction of the negative and positive sides of the process of decay, the subtraction of forms, comprises the potentials of the infinite latitudes of forms. Negarestani's first axiom is: "decay is a building process; it has a chemical slant and a differential ... dynamic distribution. The process of decay builds new states of extensity, affect, magnitude, and even integrity from and out of system or formation without nullifying or reforming it" (Negarestani, 2010). Refugee camps are part of this process of building an infrastructure that de-territorializes the refugee as an arche-fossil of the post-human era. The possible putrefaction of arche-fossils, and the time connected to the processes of formation, deals with the relationship between anachronism and 'decay.'

"...The process of decay generates differential forms by limitrophically subtracting from the rotten object" writes Negarestani in defining the architecture and politics of decay that can be read through the constellation of objects and models (Negarestani, 2010). Warfare, ecological disaster and technological collapse have deep impacts in our everyday life and designate our future spatial infrastructure. Ecological disasters are core reasons for governments to create policies for the 
further demolishing of ecological landscapes and inhabitants. In the case of the refugee camp, sustaining the livelihood such as dwelling, food, health and related emergency issues are is the basic forces for the zoning of a camp plan. This form of dwelling and its zoning plan is a production of space and its process is about a continuous negotiation of public space, which is based on several affects such as border politics and its juridical justification, the negotiation of humanitarian aid and political agencies. The design program of a camp aims to supply needs of dwelling for a community on the spatial scale of the neighborhood, village or small city. In this way, the refugee community is often taken as a homogenous entity, unfortunately dismissing not only its kinship, but also its tribal and religious networks. ARQ

A previous version of this text was published in: $2000+$ The Urgencies of Architectural Theory. Edited by James Graham (New York: Columbia Books on Architecture and the City, 2015), This text is also a part of a chapter in the book Missions: from the Unmanned Architecture and Security Series, edited by Ethel Baraona, Marina Otero and Malkit Shoshan (dpr-barcelona, 2016).

\section{PELIN TAN}

$<$ pelintan@gmail.com>

Sociologist, Ankara University, Ankara, Turkey (1997). PhD in Art History, Technical University of Istanbul, Turkey (2011). Post-doctoral studies in artistic research, Massachusetts Institute of Technology, MIT,USA (2012). Her research is focused on urban conflict and territorial politics, gift economy, and the condition of labor. Her articles have been published in Domus, Bauwelt, E-flux, among others. She has co-curated the exhibition Adhocracy (Istanbul, 2012; New York, 2013; Athens, 2015). She has lectured in different universities across the world, and her texts have been published in Promiscuous Encounters (2014), Adhocracy Reader (2015), 2000+: The Urgencies of Architectural Theory (2015), among others. Her books include Arazi / Territory (Sternberg Press, 2015), and Unconditional Hospitality and Threshold Architecture (dpr-barcelona, 2015). Tan, is also lead author of Towards Urban Society - International Panel on Social Progress -IPSP- (Saskia Sassen \& Edgar Pieterse, 2017). She is currently based in Mardin and Istanbul, and is associate professor at the Faculty of Architecture, Mardin Artuklu University, Mardin, Turkey.

\section{BIBLIOGRAFÍA / BIBLIOGRAPHY}

AgA B B n, Giorgio. State of Exception. Translated by Kevin Attell. Chicago: University of Chicago Press, 2005.

A Ga m B En, Giorgio. Homo Sacer: Sovereign Power and Bare Life. Stanford, ca: Stanford University Press, 1998.

AGIER, Michel. «Between War and City: Towards an Urban Anthropology of Refugee Camps», Ethnography 3, 2002.

CRITCHLEY, Simon. Infinitely demanding: ethics of commitment, politics of resistance. London; New York: Verso, 2007.

CRITCHLEY, Simon. «Breaking the Social Contract», Interview with Pelin Tan, E-flux Journal 38 (IO-20I2). Available online at: www.e-flux.com/ journal/breaking-the-social-contract/

F R A N K E, Anselm (Ed.). Territories: 1slands, Camps and Other States of Utopia Cologne: Walter Köning, 2003.

HER Z, Manuel. «Refugee Camps - or - ldeal Cities in Dust and Dirt». In: Urban Transformation. Berlin: Ruby Press, 2008.

Hilal, Sandi. «Abu Ata, Architect: A Play in Four Acts» (2008) Campus in Camps <http://www.campusincamps.ps/wp-content/uploads/2012/12/ Sandi-Hilal_Fawwar-play-Final.pdf $>$ (last accessed March 8, 20I6)

NEGARESTAN , Reza. «Undercover Softness: An Introduction to the Architecture and Politics of Decay,» Collapse Vol. Vl «Geo/Philosophy» (January, 20Io)

PET TI, Alessandro. «Architecture of Exile» (2015). Campus in Camps $<$ http://www.campusincamps.ps/architecture-exile/> (last accessed March 8, 20I6)

PET TI, Alessandro; Hilal, Sandi; weizman, Eyal. Architecture After Revolution. Berlin: Sternberg Press, 20I4.

SCHміт T, Carl (1888-I985). Political theology: four chapters on the concept of sovereignty. Chicago: University of Chicago Press, 2005 [1922].

TAN, Pelin. «Arquitectura tras la crisis: un viaje por las prácticas contemporáneas de la comunalización». ARQ 9I «Común/Common» (Diciembre, 20I5):II4-I2I.

TAN, Pelin; HÜ NER, Emre. «Conversation, The Forms of Non-Belonging». Supercommunity, Project, 56th Venice Biennale. Venice: E-flux, 2015.

т Ü R к, Duygu. Öteki, Düşman, Olay: Levinas, Schmitt ve Badiou'da Etik ve Siyaset. Istanbul: Metis Publishing, 2013.

wo Dicz Ko, Krzysztof. Krzysztof Wodiczko: New York City tableaux, Tompkins Square, the Homeless vehicle project. New York: Exit Art, I990. 